\title{
Dissolved organic carbon and apparent oxygen utilization in the Atlantic Ocean
}

\author{
Xi Pan ${ }^{a}$, Eric P. Achterberg a,d,*, Richard Sanders ${ }^{\mathrm{b}}$, Alex J. Poulton ${ }^{\mathrm{b}}$, \\ Kevin I.C. Oliver ${ }^{\mathrm{a}}$, Carol Robinson ${ }^{\mathrm{c}}$ \\ a National Oceanography Centre Southampton, Ocean and Earth Science, University of Southampton, Southampton SO14 3ZH, UK \\ ${ }^{\mathrm{b}}$ National Oceanography Centre Southampton, Southampton SO14 3ZH, UK \\ ' School of Environmental Sciences, University of East Anglia, Norwich NR4 7TJ, UK \\ ${ }^{\mathrm{d}}$ GEOMAR, Helmholtz Centre for Ocean Research, 24148 Kiel, Germany
}

\section{A R T I C L E I N F O}

\section{Article history:}

Received 13 March 2013

Received in revised form

27 November 2013

Accepted 2 December 2013

Available online 24 December 2013

\section{Keywords:}

Dissolved organic carbon

Apparent oxygen utilization

Particulate organic carbon

Carbon export

Atlantic Meridional Transect

\begin{abstract}
A B S T R A C T
Dissolved organic carbon (DOC) distributions along two Atlantic Meridional Transects conducted in 2005 in the region between $47^{\circ} \mathrm{N}$ and $34^{\circ} \mathrm{S}$ showed clear latitudinal patterns. The DOC concentrations in the epipelagic zone $(0-100 \mathrm{~m})$ were the highest $(70-90 \mu \mathrm{M})$ in tropical and subtropical waters with stable mixed layers, and lowest $(50-55 \mu \mathrm{M})$ at the poleward extremities of the transects due to deep convective mixing supplying low DOC waters to the surface. A decrease in DOC occurred with depth, and lowest DOC concentrations (41-45 $\mu \mathrm{M})$ in the 100-300 m depth range were observed in the equatorial region due to upwelling of low DOC waters. A strong relationship between DOC and AOU was observed in the $\sigma-t 26-26.5$ isopycnal layer which underlies the euphotic zone and outcrops at the poleward extremities of the North and South Atlantic Subtropical Gyres (NASG and SASG) in the region ventilating the thermocline waters. Our observations reveal significant north-south variability in the DOC-AOU relationship. The gradient of the relationship suggests that $52 \%$ of the AOU in the $\sigma-t 26-26.5$ density range was driven by DOC degradation in the NASG and 36\% in the SASG, with the remainder due to the remineralisation of sinking particulate material. We assess possible causes for the greater contribution of DOC remineralisation in the NASG compared to the SASG.
\end{abstract}

(c) 2013 Elsevier Ltd. All rights reserved.

\section{Introduction}

The biological carbon pump (BCP) forms an important component of the global carbon cycle (e.g., Thingstad, 1993; Ducklow et al., 2001; Hansell and Carlson, 2001a; Omta et al., 2006). Following the synthesis of $\mathrm{CO}_{2}$ into organic material during photosynthesis, creating a surface water dissolved inorganic carbon (DIC) deficit (Tsurushima et al., 2002), subsequent processes remove some of this organic matter into the oceans' interior where it is remineralised, causing a deficit in dissolved oxygen (Doval and Hansell, 2000; Hansell and Carlson, 2001a; Garcia et al., 2005). On a global scale, the upper ocean DIC deficit is balanced by a transfer of $\mathrm{CO}_{2}$ from the atmosphere to the upper ocean, hence the $\mathrm{BCP}$ represents a sink for atmospheric $\mathrm{CO}_{2}$ (Hansell and Carlson, 2001a). Two mechanisms cause the downward transfer of organic matter: (1) passive sinking of particulate organic carbon (POC), and (2) transfer to depth by overturning circulation at high latitudes or subduction in subtropical gyres of dissolved organic

\footnotetext{
* Corresponding author.

E-mail address: eachterberg@geomar.de (E.P. Achterberg).
}

carbon (DOC) that has accumulated in the surface ocean (Hansell, 2002). The spatial variability of the relative contributions of POC and DOC to carbon sequestration is however largely unclear, which is caused by a paucity of high quality DOC data. Recent DOC observations on US Climate Variability (CLIVAR) cruises in the North Atlantic, Pacific and Southern Ocean have started to redress this issue (Hansell, 2002; Carlson et al., 2010; Hansell et al., 2012). In this paper we present observations of DOC concentrations in the tropical and subtropical North and South Atlantic Ocean and use them to estimate the relative contributions of the remineralisation of DOC and POC to apparent oxygen utilization (AOU).

DOC is a continuum of labile, semi-labile, and refractory pools, which are increasingly resistant to photochemical and/or microbial breakdown (Kirchman et al., 1993; Hansell et al., 2012). In the open ocean, DOC originates from in situ biological processes, including plankton exudation/excretion (Collos et al., 1992), grazing (Søndergaard et al., 2000), and cell lysis (Nagata, 2000). However, the ultimate DOC source is primary production (Carlson et al., 1998), at a reported rate of DOC production equivalent to $4-41 \%$ of total integrated primary production, with the highest observed values in oligotrophic waters and lowest in upwelling regions (Teira et al., 2001). The remineralisation of DOC 
by heterotrophic prokaryotes is the major removal mechanism (Azam, 1998), although direct assimilation by some marine eukaryotes (Azam and Hodson, 1977; Sherr and Sherr, 1988) may also be important. Accumulation of DOC in surface waters is therefore dependent on a decoupling of microbial consumption from primary production (Carlson et al., 1998). In addition, DOC accumulation is dependent on water column stability, with strongly stratified subtropical oligotrophic waters showing the highest potential for accumulation (Carlson et al., 2010).

The relationship between DOC and AOU, the latter integrating all respiratory processes within a water body since its isolation from the atmosphere, has been intensively studied. Thomas et al. (1995) found a weak relationship in the Equatorial Atlantic $(<700 \mathrm{~m}$ ), while Hansell et al. (1993) observed no covariation in the Southern California Bight $(<1000 \mathrm{~m})$. However, Abell et al. (2000) found a strong correlation between total organic carbon $(\mathrm{TOC}=\mathrm{DOC}+\mathrm{POC})$ and AOU in the North Pacific Subtropical Gyre at water depths $<350 \mathrm{~m}$. In recent work, Carlson et al. (2010) reported a good correlation between DOC and AOU in the mesoand bathypelagic North Atlantic, and Santinelli et al. (2010) made similar observations for this part of the water column of the Mediterranean Sea.

The reported contribution of DOC degradation to AOU varies considerably from site to site. Thomas et al. (1995) reported that $10-20 \%$ of AOU was derived from DOC remineralisation in the upper $700 \mathrm{~m}$ of the Equatorial Atlantic. Doval and Hansell (2000) showed that the degradation of TOC contributed to $35-50 \%$ and $30-45 \%$ of AOU in the South Pacific and the central Indian Oceans, respectively, at depths from 50 to $300 \mathrm{~m}$. Abell et al. (2000) found that $35-80 \%$ of AOU can be explained by TOC remineralisation in the upper $350 \mathrm{~m}$ in the North Pacific Subtropical Gyre. Hansell and Carlson (2001b) suggested that TOC decomposition accounted for $15-40 \%$ of AOU based on a 5-year time series of observations in the 100-400 m depth range at the Bermuda Atlantic Time Series (BATS) site in the Sargasso Sea. Carlson et al. (2010) reported that between $7 \%$ and $28 \%$ of AOU could be assigned to DOC oxidation in waters below $100 \mathrm{~m}$ in the North Atlantic, and Santinelli et al. (2010) reported that $38 \%$ of AOU was due to DOC oxidation in the Levantine Intermediate Water of the Mediterranean Sea.

Hence the proportion of AOU derived from DOC remineralisation appears to have a large range, from $<20 \%$ in equatorial regions to $\sim 80 \%$ in subtropical gyres. The fraction of AOU attributable to DOC degradation is an index of the relative importance of DOC transfer to depth through overturning circulation and subduction versus particle export. Therefore one would expect regional variability in the importance of particle sinking versus DOC export to the BCP. We analyzed DOC and AOU observations from two Atlantic Meridional Transects. Firstly we report the spatial distribution of DOC concentrations. We then investigate the bulk relationship between DOC and AOU in water masses isolated from the atmosphere. Finally we derive separate DOC:AOU relationships for the two gyres to examine spatial variability in the relative importance of the factors which cause oxygen utilization and hence carbon sequestration in subsurface waters.

\section{Methodology}

\subsection{Sampling}

We sampled during Atlantic Meridional Transect (AMT) cruises 16 (19 May-29 June 2005) and 17 (15 October-28 November 2005) onboard the RRS Discovery between South Africa and the UK (Fig. 1). Water samples for the determination of DOC, oxygen, nitrate plus nitrite and chlorophyll concentrations were collected from 10 to 12 depths in the upper $300 \mathrm{~m}$ during daily pre-dawn
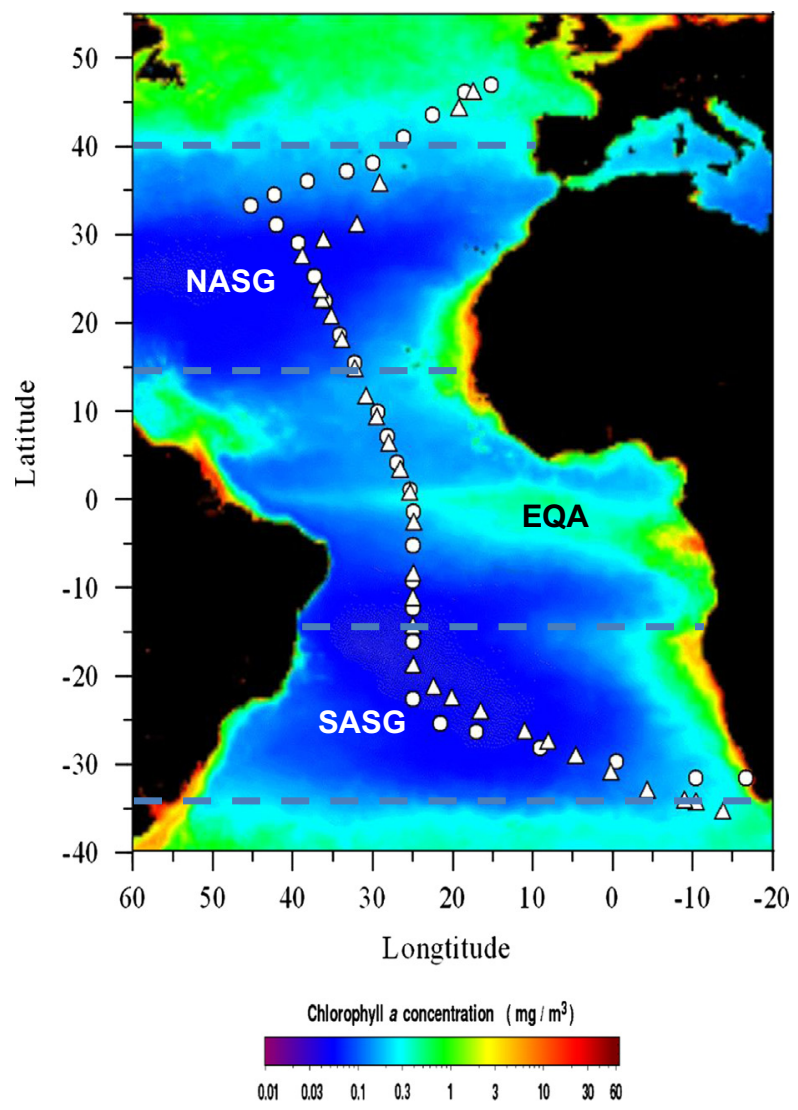

Fig. 1. Cruise track and locations of sampling stations for Atlantic Meridional Transect (AMT)-16 (19 May-29 June 2005) and -17 (15 October-28 November 2005). Circles indicate stations sampled on AMT-16, while triangles indicate stations sampled on AMT-17. The composite satellite image of chlorophyll a distribution was obtained from SeaWiFS (for year 2000; NASA, USA)

deployments of a rosette sampler equipped with $24 \times 201$ OTE (Ocean Test Equipment) bottles and a Sea-Bird 911 CTD equipped with a Seabird oxygen sensor. On every third day during AMT-16 we collected samples from a deeper cast down to $\sim 1000 \mathrm{~m}$.

\subsection{Dissolved organic carbon}

Samples $(250 \mathrm{ml})$ for DOC were filtered immediately through preashed $\left(450{ }^{\circ} \mathrm{C}, 6 \mathrm{~h}\right)$ Whatman $\mathrm{GF} / \mathrm{F}(0.7 \mu \mathrm{m}$ pore size $)$ filters using an acid-cleaned glass filtration unit under moderate vacuum $(<15 \mathrm{kPa})$. The filtrate was collected in $20 \mathrm{~mL}$ pre-combusted $\left(450^{\circ} \mathrm{C}, 6 \mathrm{~h}\right)$ glass ampoules, acidified to $\mathrm{pH} 2$ using hydrochloric acid (Fisher, Aristar Grade), flame sealed, and dark-stored in a fridge $\left(4^{\circ} \mathrm{C}\right)$ for subsequent analysis in our shore-based laboratory. Dissolved organic carbon concentrations were determined using a high-temperature catalytic combustion technique with a Shimadzu TOC-5000A analyzer following Pan et al. (2005). Acidified deep Sargasso Sea water, preserved in glass ampoules and provided by D. Hansell (University of Miami), served as a certified reference material. Our daily analysis of the reference material yielded a mean concentration of $45.2 \pm 1.2 \mu \mathrm{M}$ $(n=96)$, which was in good agreement with the certified value of 44-46 $\mu \mathrm{M}$ (Hansell and Carlson, 2001a). Our analytical precision, based on the coefficient of variation (standard deviation/mean) of consecutive injections (typically $3-5$ injections) of a single sample, was typically $<1 \%$.

\subsection{Dissolved oxygen}

Water samples were drawn from 4 to 6 OTE bottles into $125 \mathrm{~mL}$ calibrated borosilicate glass bottles and fixed immediately using 
manganous sulfate and alkaline iodide solutions following Robinson et al. (2006). They were then acidified using sulfuric acid and the liberated iodine titrated against sodium thiosulfate using an automated photometric endpoint detector (Williams and Jenkinson, 1982). Oxygen concentrations were calculated following Robinson et al. (2006). The precision (coefficient of variation) for dissolved oxygen analyses, determined by measuring dissolved oxygen from each of 12 OTE bottles fired at the same depth $(105 \mathrm{~m})$, was $<0.03 \%$. The relationship between the Winkler oxygen concentrations and the Seabird oxygen sensor values for each bottle sampled was evaluated using a model-II regression analysis for each CTD station. The drift of the dissolved oxygen sensor over the course of each cruise was small, with only minor changes between the two cruises. Hence a single regression equation for the Winkler oxygen and Seabird oxygen sensor data (in $\mu \mathrm{mol} \mathrm{kg} \mathrm{kg}^{-1}$ ) was used to describe the entire dataset:

$\mathrm{O}_{2}$ Winkler $=1.0361 \pm 0.0619 \mathrm{O}_{2 \mathrm{SEB}}+1.0151 \pm 0.0185$

We then applied the regression equations to compute dissolved oxygen concentrations for AMT-16 and -17 for the remaining OTE bottles sampled for DOC, which had not been sampled for dissolved oxygen. Finally, oxygen saturation and AOU were calculated using calibrated CTD data and the solubility equations of Garcia and Gordon (1992) and coefficients of Benson and Krause (1984).

\subsection{Nitrate plus nitrite, chlorophyll-a}

Micromolar nitrate plus nitrite concentrations were determined on-board ship using a 5-channel segmented flow colorimetric autoanalyzer (Bran+Luebbe, AAIII) following the method of Brewer and Riley (1965), with a detection limit of $0.1 \mu \mathrm{M} \mathrm{N}$. Total chlorophyll-a concentrations were determined fluorimetrically using a Turner Designs TD-700 fluorometer calibrated with pure chlorophyll-a standards (Sigma, UK); full details of the chlorophyll methodology can be found in Poulton et al. (2006).

\section{Results and discussion}

\subsection{Density structure, inorganic nutrients and chlorophyll-a}

Details of the broadscale hydrographic features observed on AMT transects (AMT-1 to -17) are presented in Robinson et al. (2006). The latitudinal density sections for AMT-16 and -17 showed equatorial upwelling, the NASG and SASG and dense (cold) waters at higher latitudes (Fig. 2a). Enhanced solar irradiation and high rainfall associated with the Intertropical Convergence Zone (Xie and Saito, 2001; Huffman et al., 1997) were the causes for the low density surface waters in the equatorial region. The surface nitrate plus nitrite concentrations were depleted, with the $1 \mu \mathrm{M} \mathrm{N}$ contour (Fig. 2b) being shallow $(\sim 50-60 \mathrm{~m})$ in temperate waters and in the equatorial region, and relatively deep ( $>100-150 \mathrm{~m}$ ) in the subtropical gyres. Total chlorophyll-a concentrations were typically low $\left(<0.1 \mathrm{mg} \mathrm{m}^{-3}\right)$ in surface waters throughout the section with a chlorophyll maximum close to the surface near the equator and at the boundaries of the subtropical gyre, and a deep chlorophyll maximum (at $\sim 100 \mathrm{~m}$ ) which reached $\sim 0.3 \mathrm{mg} \mathrm{m}^{-3}$ in the subtropical gyres (Fig. 2c).

\subsection{Dissolved organic carbon and apparent oxygen utilization}

On both AMT-16 and -17 cruises, enhanced DOC concentrations ( $>80 \mu \mathrm{M}$ ) were observed in surface $(<50 \mathrm{~m}$ ) waters of the equatorial Atlantic ( $\sim 15^{\circ} \mathrm{S}$ to $\sim 15^{\circ} \mathrm{N}$ ). On AMT-16 these high values extended to $\sim 25^{\circ} \mathrm{S}$ (Fig. 2d). Away from this equatorial region, DOC concentrations in the epipelagic zone $(0-100 \mathrm{~m})$ decreased to ca. $50 \mu \mathrm{M}$ at the polar extremities of the gyres (Fig. 3) as a result of overturning circulation causing a dilution of DOC concentrations in near-surface waters with low-DOC waters from depth. Equatorial upwelling of deep low DOC waters was evident in the anomalously low DOC concentrations $(45-55 \mu \mathrm{M})$ observed in the epipelagic zone between 10 and $15^{\circ} \mathrm{N}$ (Fig. 3); the low DOC samples were collected below the mixed layer (50-60 m). A vertical gradient was observed in DOC concentrations throughout the latitudinal section. In the equatorial Atlantic the DOC concentrations ranged from $75-88 \mu \mathrm{M}$ in the upper $40 \mathrm{~m}$, and decreased to $65-70 \mu \mathrm{M}$ at $100 \mathrm{~m}$ and $50-55 \mu \mathrm{M}$ at $300 \mathrm{~m}$ (Fig. $2 \mathrm{~d}$ ). In the subtropical Atlantic gyres (SASG between $\sim 35^{\circ} \mathrm{S}$ and $\sim 15^{\circ} \mathrm{S}$; NASG between $\sim 15^{\circ} \mathrm{N}$ and $\sim 35^{\circ} \mathrm{N}$ ) DOC concentrations varied from $70-80 \mu \mathrm{M}$ in the upper $40 \mathrm{~m}$, and decreased to $65-70 \mu \mathrm{M}$ at $100 \mathrm{~m}$ and $50-55 \mu \mathrm{M}$ at $300 \mathrm{~m}$ (Fig. 2d). Below $1000 \mathrm{~m}$, DOC concentrations were rather uniform, ranging from $43-45 \mu \mathrm{M}$ (data not shown). In surface waters, AOU concentrations were close to zero (Fig. 2e) implying that surface water dissolved oxygen concentrations were in equilibrium with the atmosphere. Deeper in the water column, AOU values of up to $25 \mu \mathrm{mol} \mathrm{kg}{ }^{-1}$ were present in the subtropical gyres at depths of $200 \mathrm{~m}$; oxygen undersaturated water was present beneath the equatorial upwelling zone (values of $\mathrm{AOU}>100 \mu \mathrm{mol} \mathrm{kg}{ }^{-1}$ at $200 \mathrm{~m})$.

\subsection{Labile, semi-labile and refractory DOC pools}

The surface ocean DOC pool is composed of fractions with different lability and turnover times. The labile fraction turns over within hours or days (Kirchman et al., 1993), and is often too small to be reliably quantified using the analytical methods employed in this study. The semi-labile component, which has a turnover time ranging from weeks to years (Carlson et al., 2004; Hansell et al., 2012), is degraded slowly in the upper ocean with this degradation being responsible for generating the concentration gradients observed in the upper ocean. Biologically refractory DOC is ubiquitous throughout the entire ocean with an average age of 4000 years in the deep North Atlantic to 6000 years in the deep North Pacific (Williams and Druffel, 1987; Bauer et al., 1992). The concentrations of DOC determined in this study are generally consistent with literature data: Abell et al. (2000) found 65-85 $\mu \mathrm{M}$ TOC in the North Pacific subtropical gyre above $50 \mathrm{~m}$; Hansell and Carlson (2001b) reported 60-70 $\mu \mathrm{M}$ above $100 \mathrm{~m}$ and $43.6 \mu \mathrm{M}$ TOC deeper than $1000 \mathrm{~m}$ in the Sargasso Sea at the BATS site; Carlson et al. (2004) observed $\sim 68 \mu \mathrm{M}$ DOC in surface waters at Hydrostation S and the BATS site. Carlson et al. (2010) observed DOC concentration maxima of ca. $76-80 \mu \mathrm{M}$ in the NASG and minima of $\sim 40-44 \mu \mathrm{M}$ at $1000 \mathrm{~m}$ in the North Atlantic. Assuming the DOC concentrations we observed at $1000 \mathrm{~m}$ were characteristic of the refractory pool (i.e., $44 \mu \mathrm{M}$ ), our data suggest that $55-80 \%$ of DOC in the upper $40 \mathrm{~m}$ was in the refractory pool. It is noted that the deep water DOC concentrations decrease as water ages increase along the deep water circulation path from the North Atlantic (e.g. $48 \mu \mathrm{M}$ in Greenland Sea) to the North Pacific ( $34 \mu \mathrm{M}$ in Gulf of Alaska) (Hansell and Carlson, 1998). Other studies have suggested that refractory DOC accounts for $62-88 \%$ of the bulk DOC pool (e.g. Carlson and Ducklow, 1995; Ogawa et al., 1999; Hansell and Carlson, 2001b).

\subsection{Spatial variability of AOU derived from DOC in subsurface waters $(\sigma-t$ 26-26.5)}

In order to determine the fraction of AOU in the oceans' interior which can be related to the remineralisation of DOC, we compared DOC and AOU in discrete density layers isolated from the atmosphere, so that changes in oxygen concentration only occur due to organic matter remineralisation and not to air-sea exchange. We 
a

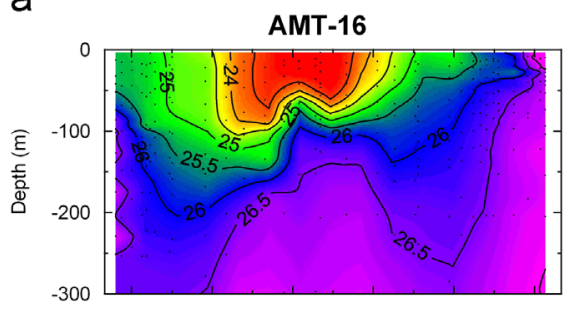

b

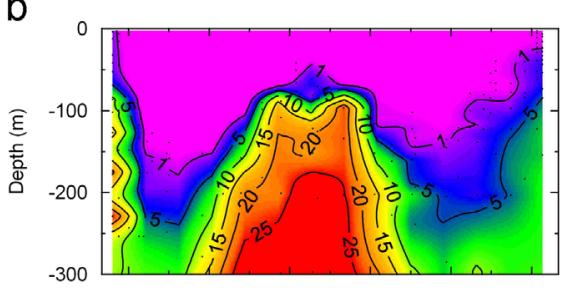

C

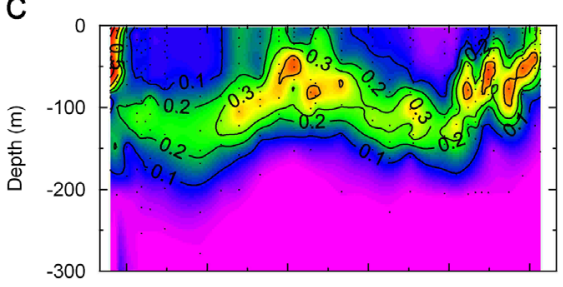

d

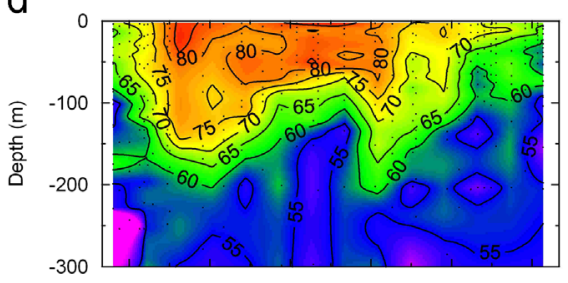

$-300$

e

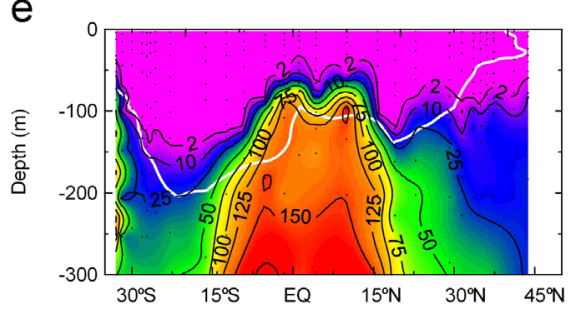

AMT-17
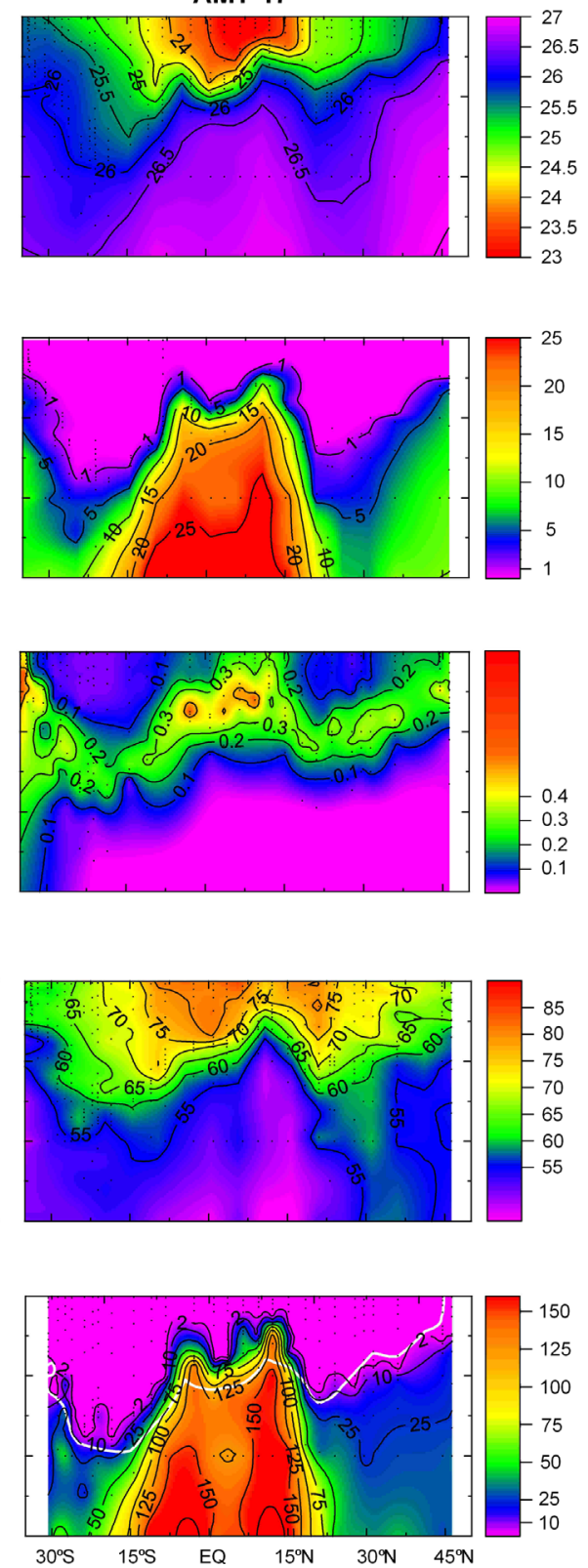

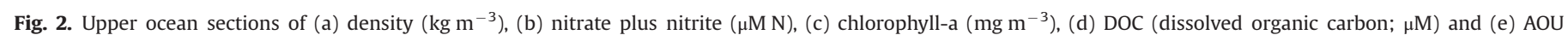
(apparent oxygen utilization; $\mu \mathrm{mol} \mathrm{kg}{ }^{-1}$ ). The white contour represents $\sigma-t 26$.

assume that variability of DOC and AOU within the waters considered is due only to the remineralisation of DOC and the associated generation of AOU, not to the mixing of various water masses (see below). Therefore the density range considered needs to be as narrow as possible, commensurate with having sufficient data to perform statistically robust analyses. We therefore only consider samples from the deep isopycnal layer $\sigma-t$ 26-26.5 (Fig. 4a), as the isopycnal $\sigma-t 26$ approximates the depth of the $2 \mu \mathrm{mol} \mathrm{kg}{ }^{-1}$ AOU isoline at both the southern and northern ends of the transect (Fig. 2e). We performed a model-II regression analysis between DOC and AOU for the entire dataset, as separate analyses of the individual cruise datasets revealed that they were statistically indistinguishable. The best fit equation was

$\mathrm{DOC}=-0.149 \pm 0.017 \mathrm{AOU}+62.909 \pm 0.835 \quad(r=-0.263)$.

The relationship between DOC and AOU can be used to evaluate the fraction of oxygen consumption related to DOC by comparing it to the slope which would occur if all the oxygen consumption was related to the remineralisation of DOC. The stoichiometric relationship between oxygen consumption and inorganic carbon production as a result of organic matter remineralisation can be expressed as a molar ratio (i.e., $\Delta C: \Delta \mathrm{AOU}=-0.72$; Anderson, 1995). We used this fixed ratio of -0.72 to allow comparison with values reported in the literature (Doval and Hansell, 2000; Carlson et al., 2010), whilst acknowledging that a range of ratios exist due to the nature of the organic matter respired (Thomas, 2002). The gradient of DOC versus AOU indicates that only a relatively small fraction $(20 \%$; -0.149 divided by -0.72 ) of the AOU within the density range $\sigma-t=26-26.5$ is driven by DOC remineralisation over the entire tropical and subtropical Atlantic Ocean, with the inference being that all, or nearly all the AOU is derived from particle decomposition. The contribution of zooplankton respiration to oxygen utilization is hard to quantify, in part due to the dynamic behavior of vertically migrating organisms. Del 


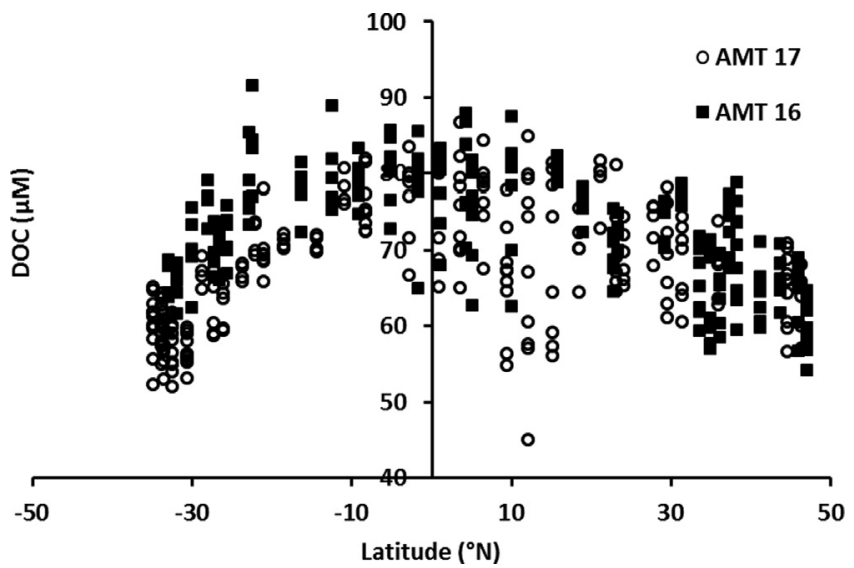

Fig. 3. DOC (dissolved organic carbon; $\mu \mathrm{M}$ ) concentrations on AMT-16 and AMT-17 against latitude for the upper $100 \mathrm{~m}$ of the water column.
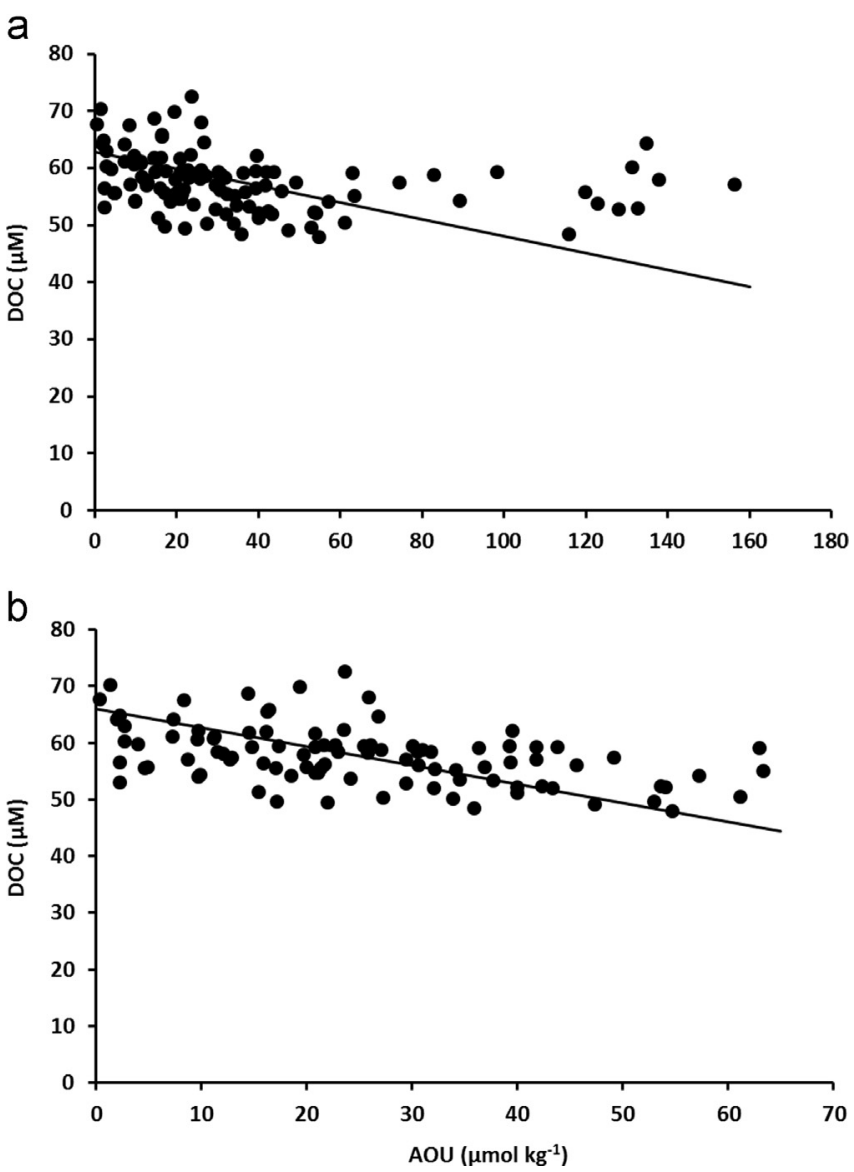

Fig. 4. (a) Regression of DOC (dissolved organic carbon; $\mu \mathrm{M}, y$-axis) on AOU (apparent oxygen utilization; $\mu \mathrm{mol} \mathrm{kg} \mathrm{kg}^{-1}, x$-axis) on the isopycnal layer $\sigma-t$ 26-26.5. The generated Model II geometric mean regression for Fig. 4a is given in the main text. (b) Regression of DOC (dissolved organic carbon; $\mu \mathrm{M}$ ) on AOU (apparent oxygen utilization; $\mu \mathrm{mol} \mathrm{kg}{ }^{-1}$ ) on the isopycnal layer 26-26.5 $\sigma_{t}$ when AOU is less than $70 \mu \mathrm{mol} \mathrm{kg}^{-1}$. The generated Model II regression for Fig. $4 \mathrm{~b}$ is given in the main text.

Giorgio and Duarte (2002) estimated the contribution as 5\% of total microplankton respiration occurring in photic and thermocline waters, and consequently significantly smaller than POC remineralisation.

However, we note that Fig. 4a contains two distinct data clusters and hence a simple linear regression for the entire dataset may be inappropriate. We have therefore separated the two clusters of data by considering separately data points with $\mathrm{AOU}>70 \mu \mathrm{mol} \mathrm{kg}^{-1}$ and those with $\mathrm{AOU}<70 \mu \mathrm{mol} \mathrm{kg}{ }^{-1}$. The former cluster is thought to reflect more refractory upwelled DOC contained within the $\sigma-t$ 26-26.5 isopycnal layer around the equatorial upwelling between $\sim 10^{\circ} \mathrm{S}$ and $\sim 15^{\circ} \mathrm{N}$. In this region DOC hardly contributed to oxygen consumption and hence we did not observe a significant correlation between DOC and AOU (Fig. 4a). The removal of data points with $\mathrm{AOU}>70 \mu \mathrm{mol} \mathrm{kg}{ }^{-1}$ produced a new regression between AOU and $\mathrm{DOC}$ in the subtropical regions: $\mathrm{DOC}=-0.332 \pm 0.035 \mathrm{AOU}+$ $66.065 \pm 1.038$ ( $r=-0.460$ ) (Fig. $4 \mathrm{~b}$ ). This suggests that $46 \%$ of oxygen consumption is derived from DOC degradation in the subtropical Atlantic region within the isopycnal layer of $\sigma-t$ 26-26.5. However, this bulk estimate conceals significant spatial variability.

\subsection{Regional variability of AOU derived from DOC}

In Fig. 5a and b the DOC and AOU data derived from the North and South Atlantic Gyres are separately presented. In the NASG (Fig. 5a) the DOC versus AOU regression yields: $\mathrm{DOC}=$ $-0.372 \pm 0.053 \mathrm{AOU}+67.663 \pm 1.378(r=-0.510)$; in the SASG: $\mathrm{DOC}=-0.259 \pm 0.044 \mathrm{AOU}+63.179 \pm 1.465(r=-0.312$, Fig. $5 \mathrm{~b})$. Thus in the NASG $52 \%$ of oxygen consumption utilizes DOC, while in the SASG the DOC contribution is 36\%. The slopes of the model II regressions were statistically different, as demonstrated using an ANOVA test which yielded a $F$ statistic value of $5.88 \times 10^{29}$ and a $p$ value of 0 .

We assume that isopycnal mixing does not have an important influence on the contribution of DOC remineralisation to AOU in the isopycnal layers of $\sigma-t$ 26-26.5 in the NASG and SASG thermocline waters observed along our cruise tracks, and thereby does not contribute to the observed differences between the gyres. The main watermass in our studied depth range in the South Atlantic is the Western South Atlantic Central Water (WSACW)
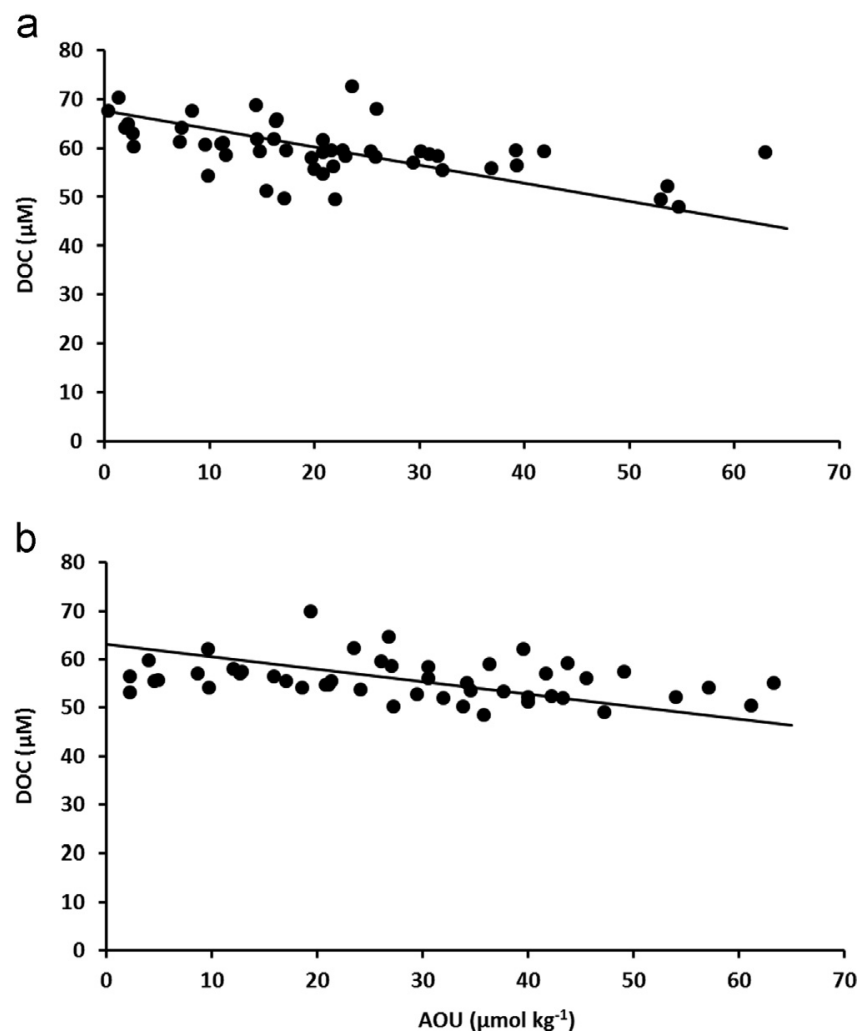

Fig. 5. Regressions of DOC (dissolved organic carbon; $\mu \mathrm{M}$ ) on AOU (apparent oxygen utilization; $\mu \mathrm{mol} \mathrm{kg}{ }^{-1}$ ) in the isopycnal range 26-26.5 $\sigma_{t}$ in $a$ (top) the North Atlantic Subtropical Gyre and $b$ (bottom) the South Atlantic Subtropical Gyre. The generated Model II regressions for Fig. 5 are presented in the main text. 
which is formed in the southwestern portion of the SASG and dominates the upper thermocline (above $500 \mathrm{~m}$ ) (Poole and Tomczak, 1999). The WSACW is separated by strong water column stratification from Eastern South Atlantic Central Water (ESACW; at depths $\sim 500-900 \mathrm{~m}$ ) formed in the Indian Ocean (Poole and Tomczak, 1999). North Atlantic Central Water (NACW) constitutes the main watermass in the North Atlantic, being formed in the North East Atlantic (north of $\sim 40^{\circ} \mathrm{N}$ ) (Poole and Tomczak, 1999). Whilst a cross equatorial western boundary flow of ESACW and WSACW penetrates into the North Atlantic supplying the thermocline waters of the Gulf of Mexico (Poole and Tomczak, 1999), further east a sharp front throughout the thermocline at $\sim 15^{\circ} \mathrm{N}$ separates the ESACW and WSACW from the NACW. Therefore, along our cruise tracks the deep isopycnal layers of $\sigma-t$ 26-26.5 in the chosen latitudinal range for the NASG $\left(\sim 15-35^{\circ} \mathrm{N}\right)$ can be considered to contain predominantly ( $>85-90 \%)$ NACW, and the SASG $\left(\sim 15-35^{\circ}\right.$ S) only contains WSACW as NCAW does not penetrate south of the equator (Poole and Tomczak, 1999). This is confirmed by potential $T-S$ diagrams (not presented) which show a clear separation of waters in the NASG and SASG, with those in the former associated with T and S characteristics reported by Poole and Tomczak (1999) for the NACW and the latter with those of the WSACW. Furthermore, through analysis of salinity fields, Armi and Stommel (1983) showed that lateral mixing was small in the NASG, observations confirmed by Jenkins (1982). Any transfer of WSACW to the waters in the NASG isopycnal layers of $\sigma-t$ 26-26.5 would result in a lowering of the contribution of DOC to AOU, and hence our observation of a significantly higher DOC contribution to AOU in the NASG compared with the SASG is not the result of isopycnal mixing processes.

The explanation for the differences in DOC contribution to AOU between the NASG and SASG may lie in the relative depths of the $\sigma-t$ 26-26.5 density range in the two gyres. In the SASG, the greatest depth that the sigma $\sigma-t 26$ reaches is $200 \mathrm{~m}$, approximately 50-100 m deeper than in the NASG (Fig. 2a). The relatively greater depth of the SASG is further illustrated by the Argo float derived maximum mixed layer depth climatology (Fig. 6a), determined on $1^{\circ} \times 1^{\circ}$ grid cells as the mean of the five deepest recorded mixed layer depths since 2000, using a density threshold mixed layer depth $\left(0.03 \mathrm{~kg} \mathrm{~m}^{-3}\right.$ ) (Holte et al., 2010).

The majority of the DOC respired in the $\sigma-t 26-26.5$ density range has penetrated the gyre via transport along the isopycnals, a small component could potentially have come from the water column above via diapycnal mixing. Any semi-labile DOC produced in the upper water column which has entered the $\sigma-t$ 26-26.5 region via diapycnal mixing would need to have mixed much deeper away from its production region in the upper ocean (i.e., euphotic zone) in the SASG than in the NASG to penetrate the density range considered. During this process it is likely that the semi-labile fraction of the DOC pool would have been respired, potentially causing the pattern observed.

We have tested this possibility by considering water mass ages in the $\sigma-t$ 26-26.5 density range. The observed asymmetry in the maximum mixed layer depth between NASG and SASG is not reflected in CFC (chlorofluoro carbon) water mass ages (Fig. 6b) for the $\sigma-t$ 26-26.5 density range, which indicate comparable age structures along the transit pathways in this density range for the two gyres. We furthermore considered the region of the water column below the $\sigma-t 25.5$ isopycnal in the SASG, which is positioned at about the same depth as the $\sigma-t 26$ isopycnal in the NASG. The gradient in the SASG of the regression equation for DOC against AOU in the density range $\sigma-t$ 25.5-26.5 is still lower than the value in the north: $\mathrm{DOC}=$ $-0.325 \pm 0.028$ AOU $+64.087 \pm 0.611(r=-0.575)$. This implies that $45 \%$ of the AOU was caused by DOC utilization for this density range in the SASG. Thus whichever density range is considered, the result that DOC remineralisation is more important in the northern gyre holds out.

Our observation that diapycnal mixing does not have an important influence on the contribution of DOC to AOU in the SASG thermocline waters is reinforced by findings from Poole and Tomczak (1999) who reported a strongly stratified thermocline with clearly separated WSACW and ESACW. Furthermore, diapycnal mixing in the thermocline of the North Atlantic is also weak (indistinguishable from zero) (Speer, 1997). We now discuss possible causes for the observed difference in behavior.

We consider two possibilities. The first is that our sampling pattern of the two gyres in relation to the regions where they are ventilated is different. The subtropical gyres are ventilated by windinduced Ekman downwelling as a result of the gyre circulation. The wind-induced subduction is augmented by lateral transfer of fluid particles across the sloping base of the mixed layer (Williams, 2001; Williams et al., 2006). The winter mixed layer thickens in a poleward direction as a result of transient surface buoyancy loss, with an increase from ca. $50 \mathrm{~m}$ in the tropics $\left(15^{\circ} \mathrm{N}\right)$ to $500 \mathrm{~m}$ or more in the subpolar gyre (e.g. at $50^{\circ} \mathrm{N}$ ) (see Fig. 6a). As a consequence, at the polar extremities of the subtropical gyres, regions of enhanced subduction rates occur that are controlled by the Lagrangian change in mixed layer thickness following the horizontal gyre circulation (Marshall et al., 1993). Observations of tritium-helium ages in the North Atlantic indicated that the density surface $\sigma-t 26.5$ in the NASG is ventilated from the northeast with a gradual aging of the tracer following the anticyclonic circulation of the gyre (Jenkins, 1987). Our sampling pattern of the two gyres was similar with a section into the gyre oblique relative to the zonal ventilation gyre boundary. However this is a somewhat subjective way to address this issue. We therefore examine the spatial distribution of CFCs in the two gyres (Fig. 6b). The CFC-12 ages in the two gyres were broadly a

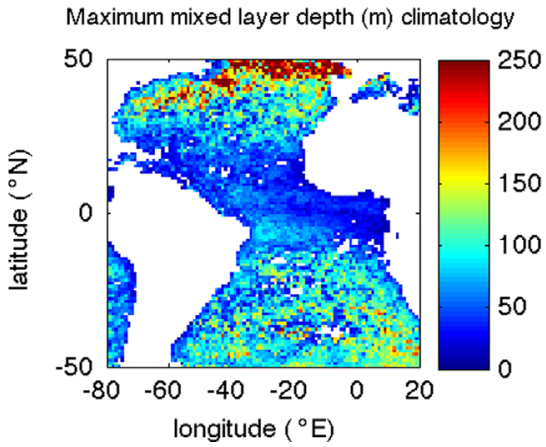

b

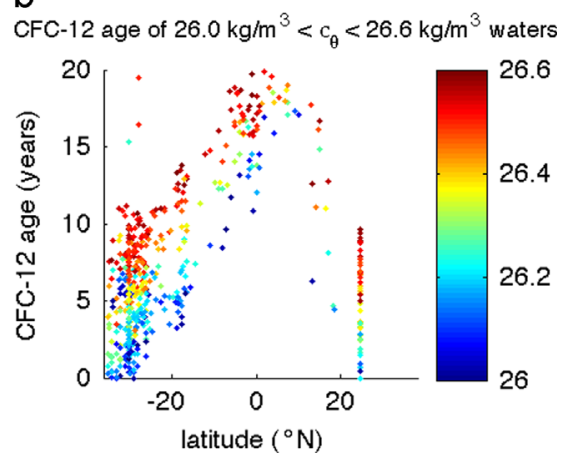

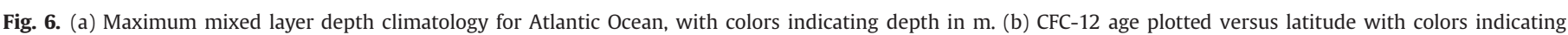

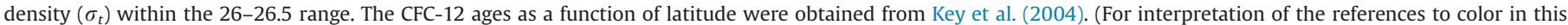
figure legend, the reader is referred to the web version of this article.) 
similar ( $<1$ to ca. $10 \mathrm{yr}$ ) (Fig. $6 \mathrm{~b}$ ) indicating that the waters we sampled in the two systems were of comparable age.

The second possibility we consider is variability in the biogeochemical characteristics of the waters in the subduction regions. The subduction process fills the $\sigma-t 26-26.5$ density space with waters aging along the transit pathway until they ventilate at the equator. If the concentrations of labile DOC in the two water masses as they subduct are different, with the SASG having lower values, then this could explain the relatively low contribution of DOC remineralisation to AOU in the SASG compared to the NASG.

We investigated this by examining the values of DOC found at low values of AOU in Fig. 4b. Values of DOC in the SASG are lower (ca. $58 \mu \mathrm{M}$ ) than those in the NASG (ca. $64 \mu \mathrm{M}$ ) implying that a greater fraction of the semi-labile DOC has been metabolized prior to subduction in this region, assuming that levels of refractory DOC are similar in the two regions. Whilst this assumption is likely to be correct we cannot formally test it because refractory DOC levels are operationally defined.

Along the AMT transect, maxima occur in abundance of bacterioplankton at the northern and southern margins of the gyres (Zubkov et al., 2000) as nutrient rich water is supplied to the photic zone, stimulating higher levels of productivity before being subducted into the oceans interior. However the maxima in bacterioplankton abundance are broader (i.e. cover wider latitude ranges) in the southern hemisphere compared to the north (Zubkov et al., 2000, Fig. 5). This is consistent with a higher fraction of any semi-labile DOC produced being metabolized prior to subduction in the southern hemisphere.

A possible mechanism which may lead to lower levels of semilabile DOC being entrained into the SASG compared to the NASG involves differential nutrient limitation of bacterial DOC consumption in the two environments. Previous work has shown that inorganic nutrient limitation prevents bacteria from utilization of organic matter and contributes to DOC accumulation (Rivkin and Anderson, 1997; Tanaka et al., 2009). Nitrogen and phosphorus co-limitation of bacterial communities has been reported by Mills et al. (2008) for the oligotrophic North Atlantic. Furthermore, much higher bacterial production responses to organic matter additions have been observed in ship-board bottle experiments in the South Atlantic compared with the North Atlantic, with North Atlantic bacterial communities only responding upon a mixed addition of inorganic and organic nutrients (Martinez-Garcia et al., 2010). These observations have been linked to the basinscale nutrient divide in the Atlantic with very low levels of surface water nitrate $(5 \pm 3 \mathrm{nM})$ in the North and South Atlantic, but much lower phosphate (ca. $9 \pm 4 \mathrm{nM}$ ) in the North compared to the South $(210 \pm 60 \mathrm{nM})$ (Moore et al., 2009, AMT-17 nutrient data). The higher phosphate availability in the South Atlantic would facilitate enhanced bacterial productivity given the relatively enhanced P-content of bacterial biomass (Norland et al., 1995) and the obligatory requirement by bacteria to use phosphorus for lipid metabolism (Van Mooy et al., 2006, 2009).

Lastly, differences in DOC quality could potentially drive the observed trends in AOU:DOC ratios between the NASG and SASG. We therefore investigated spatial variations in DOC quality as derived from observations of chromophoric dissolved organic matter (CDOM) and fluorescent DOM (e.g. Jorgensen et al., 2011; Nelson et al., 2010; Kitidis et al., 2006), and analyses of the molecular composition of DOM (Flerus et al., 2012). The results by these workers indicate evidence of regional differences in the Atlantic Ocean, but unfortunately insufficient data are available for these variables to specifically compare the NASG and SASG.

\section{Conclusions}

The fractional contribution of DOC remineralisation to AOU in layers isolated from the atmosphere varies within the Atlantic
Ocean. In the NASG $52 \%$ of AOU is due to DOC remineralisation compared with $36 \%$ in the SASG. We speculate that this is due to more labile DOC entering the northern thermocline than the southern one, possibly due to nutrient limitation of bacterial productivity in the northern subduction zone. Regardless of its cause, the difference in behavior in the two subtropical gyres has an important practical consequence. DOC transfer in layers isolated from the atmosphere appears to be a less significant route for carbon export in the SASG compared with the NASG. The controlling factors for the latitudinal variations in DOC mineralization warrant further investigation, as future changes in surface ocean temperature, water column stratification and nutrient supply to the surface oceans may affect DOC export from the surface ocean.

\section{Acknowledgments}

We thank Malcolm Woodward and Katie Chamberlain for nitrate analyses, Clare Ostle for Model II regression analyses, Niki Gist for dissolved oxygen analyses, Johannes Karstensen for discussions on isopycnal mixing, and Joaquin Pampin-Baro for providing ODV plots. The principal scientists, officers and crew of RRS Discovery cruises D294 and D299 and the technical support of the National Marine Facilities (NMF) staff are recognized with appreciation for the success of the cruises. We appreciate the comments by two anonymous reviewers which improved the manuscript. This study was supported by the UK Natural Environment Research Council through the Atlantic Meridional Transect consortium (NER/O/S/2001/00680). The contribution number is 174 for the AMT program.

\section{References}

Abell, J., Emerson, S., Renaud, P., 2000. Distributions of TOP, TON and TOC in the North Pacific subtropical gyres: Implications for nutrient supply in the surface ocean and remineralisation in the upper thermocline. J. Mar. Res. 58, 203-222.

Anderson, L.A., 1995. On the hydrogen and oxygen content of marine phytoplankton. Deep Sea Res. I 42, 1675-1680.

Armi, L., Stommel, H., 1983. Four views of a portion of the North Atlantic subtropical gyre. J. Phys. Oceanogr. 13, 828-857.

Azam, F., 1998. Microbial control of oceanic carbon flux: the plot thickens. Science 280, 694-696.

Azam, F., Hodson, R.E., 1977. Size distribution and activity of marine microheterotrophs. Limnol. Oceanogr. 22, 492-501.

Bauer, J.E., Williams, P.M., Druffel, E.R.M., 1992. ${ }^{14} \mathrm{C}$ activity of dissolved organic carbon fractions in the north-central Pacific and Sargasso Sea. Nature 357 667-670.

Benson, B.B., Krause, D., 1984. The concentration and isotopic fractionation of oxygen dissolved in freshwater and seawater in equilibrium with the atmosphere. Limnol. Oceanogr. 29, 620-632.

Brewer, P.G., Riley, J.P., 1965. The automatic determination of nitrate in seawater. Deep Sea Res. 12, 765-772.

Carlson, C.A., Ducklow, H.W., 1995. Dissolved organic carbon in the upper ocean of the central equatorial Pacific Ocean, 1992: daily and finescale vertical variations. Deep Sea Res. II 42, 639-656.

Carlson, C.A., Ducklow, H.W., Hansell, D.A., Smith, W.O., 1998. Organic carbon partitioning during spring phytoplankton blooms in the Ross Sea polynya and the Sargasso Sea. Limnol. Oceanogr 43, 375-386.

Carlson, C.A., Giovannoni, S.J., Hansell, D.A., Goldberg, S.J., Parsons, R., Vergin, K., 2004. Interactions among dissolved organic carbon, microbial processes, and community structure in the mesopelagic zone of the northwestern Sargasso Sea. Limnol. Oceanogr. 49, 1073-1083.

Carlson, C.A., Hansell, D.A., Nelson, N.B., Siegel, D.A., Smethie Jr., W.M., Khatiwala, S., Meyers, M.M., Wallner, E., 2010. Dissolved organic carbon export and subsequent remineralization in the mesopelagic and bathypelagic realms of the North Atlantic basin. Deep-Sea Res. II 57, 1433-1445.

Collos, Y., Dohler, G., Biermann, I., 1992. Production of dissolved organic nitrogen during uptake of nitrate by Synedra planctonica: Implications from estimating new production in the oceans. J. Plankton Res. 14, 1025-1029.

Del Giorgio, P.A., Duarte, C.M., 2002. Respiration in the open ocean. Nature 420 379-384, http://dx.doi.org/10.1038/nature01165.

Doval, M.D., Hansell, D.A., 2000. Organic carbon and apparent oxygen utilization in the western South Pacific and the central Indian Oceans. Mar. Chem. 68, 249-264.

Ducklow, H.W., Steinberg, D.K., Buesseler, K.O., 2001. Upper ocean carbon export and the biological pump. Oceanography $14,50-58$. 
Flerus, R., Lechtenfeld, O.J., Koch, B.P., McCallister, S.L., Schmitt-Kopplin, P., Benner, R. Kaiser, K., Kattner, K., 2012. A molecular perspective on the ageing of marine dissolved organic matter. Biogeosciences 9 (1935-1955), 2012.

Garcia, H.E., Gordon, L.I., 1992. Oxygen solubility in seawater: better fitting equations. Limnol. Oceanogr. 37, 1307-1312.

Garcia, H.E., Boyer, T.P., Levitus, S., Locarnini, R.A., Antonov, J., 2005. On the variability of dissolved oxygen and apparent oxygen utilisation content for the upper world ocean: 1955 to 1998. Geophys. Res. Lett. 32, L09604, http://dx. doi.org/10.1029/2004GL022286.

Hansell, D.A., 2002. DOC in the global ocean carbon cycle. In: Hansell, D.A., Carlson, C.A. (Eds.), Biogeochemistry of Marine Dissolved Organic Matter. Academic Press, San Diego, pp. 685-715.

Hansell, D.A. Williams, P.M. Ward, B.B., 1993. Measurements of DOC and DON in the Southern California Bight using oxidation by high temperature combustion. Deep Sea Res. I 40, 219-234.

Hansell, D., Carlson, C., 1998. Net community production of dissolved organic carbon. Global Biogeochem. Cycl 12, 443-453.

Hansell, D.A., Carlson, C.A., 2001a. Marine dissolved organic matter and the carbon cycle. Oceanography 14, 41-49.

Hansell, D.A., Carlson, C.A., 2001b. Biogeochemistry of total organic carbon and nitrogen in the Sargasso Sea: control by convective overturn. Deep Sea Res. Il 48, 1649-1667.

Hansell, D.A., Carlson, C.A., Schlitzer, R., 2012. Net removal of major marine dissolved organic carbon fractions in the subsurface ocean. Glob. Biogeochem. Cycle26, GB 1016, http://dx.doi.org/10.1029/2011GB004069.

Holte, J., Gilson, J., Talley, L., Roemmich, D., 2010. Argo Mixed Layers. Scripps Institution of Oceanography/UCSD 〈http://mixedlayer.ucsd.edu〉, (accessed 19.07.12)

Huffman, G.J., Adler, R.F., Arkin, P., Chang, A., Ferraro, P., Gruber, A., Janowiak, J. McNab, A., Rudolf, B., Schneider, U., 1997. The Global Precipitation Climatology Project (GPCP) combined precipitation dataset. Bull. Am. Meteorol. Soc. 78, $5-20$.

Jenkins, W.J., 1987. 3H and 3He in the beta triangle: observations of gyre ventilation and oxygen utilization rates. J. Phys. Oceanogr. 17, 763-783.

Jenkins, W.J., 1982. Oxygen utilization rates in North Atlantic subtropical gyre and primary production in oligotrophic systems. Nature 300, 246-248.

Jorgensen, L., Stedmon, C.A., Kragh, T., Markager, S., Middelboe, M., Søndergaard, M., 2011. Global trends in the fluorescence characteristics and distribution of marine dissolved organic matter. Mar. Chem. 126, 139-148.

Key, R.M., Kozyr, A., Sabine, C.L., Lee, K., Wanninkhof, R., Bullister, J.L., Feely, R.A. Millero, F.J., Mordy, C., Peng, T.-H., 2004. A global ocean carbon climatology: results from Global Data Analysis Project (GLODAP). Glob. Biogeochem. Cycle 18, GB4031, http://dx.doi.org/10.1029/2004GB002247.

Kirchman, D.L., Lancelot, C., Fasham, M., Legendre, L., Radach, G., Scott, M., 1993. Dissolved organic matter in biogeochemical models of the ocean. In: Evans, G.T. Fasham, M.J.R. (Eds.), Towards a Model of Ocean Biogeochemical Processes. Springer-Verlag, Berlin, pp. 209-225.

Kitidis, V., Stubbins, A.P., Uher, G., Upstill-Goddard, R.C., Law, C.S., Woodward, E.M. S., 2006. Variability of chromophoric organic matter in surface waters of the Atlantic Ocean. Deep-Sea Res. II 53, 1666-1684.

Marshall, J.C., Nurser, A.J.G., Williams, R.G., 1993. Inferring the subduction rate and period over the North Atlantic. J. Phys. Oceanogr. 23, 1315-1329.

Martınez-Garcıa, S., Fernandez, E., Calvo-Dıaz, A., Maranon, E., Moran, X.A.G., Teira, E. 2010. Response of heterotrophic and autotrophic microbial plankton to inorganic and organic inputs along a latitudinal transect in the Atlantic Ocean. Biogeosciences 7, 1701-1713, http://dx.doi.org/10.5194/bg-7-1701-2010.

Mills, M.M., Moore, C.M., Langlois, R., Milne, A., Achterberg, E.P., Nachtigall, K. Lochte, K., Geider, R., La Roche, J., 2008. Nitrogen and phosphorous colimitation of bacterial productivity and growth in the oligotrophic subtropical North Atlantic. Limnol. Oceanogr. 53, 824-834.

Moore, C.M., Mills, M.M., Achterberg, E.P., Geider, R.J., La Roche, J., Lucas, M.I., McDonagh, E.L., Pan, X., Poulton, A.J., Rijkenberg, M.J.A., Suggett, D.J., Ussher, S.J. Woodward, E.M.S., 2009. Iron supply controls the coupling of nitrogen to phosphorus in the Atlantic Ocean. Nat. Geosci. 2, 867-871, http://dx.doi.org/10. 1038/ngeo667.

Nagata, T., 2000. Production mechanisms of dissolved organic matter. In: Kirchman, D.L. (Ed.), Microbial Ecology of the Oceans. Wiley, New York, pp. 121-152.

Nelson, N.B., Siegel, D.A., Carlson, C.A., Swan, C.M., 2010. Tracing global biogeochemical cycles and meridional overturning circulation using chromophoric dissolved organic matter. Geophys. Res. Lett. 37, L03610, http://dx.doi.org/10. 1029/2009GL042325.

Norland, S., Fagerbakke, K.M., Heldal, M., 1995. Light element analysis of individua bacteria by X-ray microanalysis. Appl. Environ. Microbiol. 61, 1357-1362.

Ogawa, H., Fukuda, R., Koike, I., 1999. Vertical distributions of dissolved organic carbon and nitrogen in the Southern Ocean. Deep Sea Res. Part I 46, 1809-1826.
Omta, A.W., Bruggeman, J., Kooijman, S.A.L.M., Dijkstra, H.A., 2006. Biological carbon pump revisited: feedback mechanisms between climate and the Redfield ratio. Geophys. Res. Lett. 33, L14613, http://dx.doi.org/10.1029/2006GL026213.

Pan, X., Sanders, R., Tappin, A.D., Worsfold, P.J., Achterberg, E.P., 2005. Simultaneous determination of dissolved organic carbon and total dissolved nitrogen on a coupled high-temperature combustion total organic carbon-nitrogen chemiluminescence detection (HTC TOC-NCD) system. J. Autom. Methods Manag. Chem. 4, 240-246.

Poole, R., Tomczak, M., 1999. Optimum multiparameter analysis of the water mass structure in the Atlantic Ocean thermocline. Deep Sea Res. I 46, 1895-1921.

Poulton, A.J., Holligan, P.M., Hickman, A., Kim, Y.-N., Adey, T.R., Stinchcombe, M.C., Holeton, C., Root, S., Woodward, E.M.S., 2006. Phytoplankton carbon fixation, chlorophyll-biomass and diagnostic pigments in the Atlantic Ocean. Deep Sea Res. Part II 53, 1593-1610.

Rivkin, R.B., Anderson, M.R., 1997. Inorganic nutrient limitation of oceanic bacterioplankton. Limnol. Oceanogr. 42, 730-740.

Robinson, C., Poulton, A.J., Holligan, P.M., Baker, A.R., Forster, G., Gist, N., Jickells, T.D., Malin, G., Upstill-Goddard, R., Williams, R.G., Woodward, E.M.S., Zubkov, M.V., 2006. The Atlantic Meridional Transect (AMT) programme: a contextual view 1995-2005. Deep Sea Res. II 53, 1485-1515.

Santinelli, C., Nannicini, L., Seritti, A., 2010. DOC dynamics in the meso and bathypelagic layers of the Mediterranean Sea. Deep Sea Res. II 57, 1446-1459. SeaWiFS (for year 2000; NASA, USA).

Sherr, E., Sherr, B., 1988. Roles of microbes in pelagic food webs: a revised concept. Limnol. Oceanogr. 33, 1225-1227.

Søndergaard, M., Williams, P.J.L.B., Cauwet, G., Riemann, B., Robinson, C., Terzic, S., Woodward, E.M.S., Worm, W., 2000. Net accumulation and flux of dissolved organic carbon and dissolved organic nitrogen in marine plankton communities. Limnol. Oceanogr. 45, 1097-1111.

Speer, K.G., 1997. A note on average cross-isopycnal mixing in the North Atlantic Ocean. Deep-Sea Res. I 44, 1981-1990.

Tanaka, T., Thingstad, T.F., Gasol, J.M., Cardelus, C., Jezberra, J., Sala, M.M., Simek, K., Unrein, F., 2009. Determining the availability of phosphate and glucose for bacteria in P-limited mesocosms of NW Mediterranean surface waters. Aquat. Microb. Ecol. 56, 81-91.

Teira, E., Pazó, M.J., Serret, P., Fernández, E., 2001. Dissolved organic carbon production by microbial communities in the Atlantic Ocean. Limnol. Oceanogr. 46, 1370-1377.

Thingstad, T.F., 1993. Microbial processes and the biological carbon pump. In: Evans, G.T., Fasham, M.J.R. (Eds.), Towards a Model of Ocean Biogeochemical Processes. Springer-Verlag, Berlin, pp. 193-208.

Thomas, C., Cauwet, G., Minster, J.F., 1995. Dissolved organic carbon in the equatorial Atlantic Ocean. Mar. Chem. 49, 155-169.

Thomas, H., 2002. Remineralization ratios of carbon, nutrients, and oxygen in the North Atlantic Ocean: a field databased assessment. Glob. Biogeochem. Cycle $16,1-12$.

Tsurushima, N., Nojiri, Y., Imai, K., Watanabe, S., 2002. Seasonal variations of carbon dioxide system and nutrients in the surface mixed layer at station KNOT ( $44^{\circ} \mathrm{N}$, $155^{\circ}$ E) in the subarctic western North Pacific. Deep Sea Res. II 49, 5377-5394.

Van Mooy, B.A.S., Bocap, G., Fredricks, H.F., Evans, C.T., Devol, A.H., 2006. Sulfolipids dramatically decrease phosphorus demand by picocyanobacteria in oligotrophic marine environments. Proc. Natl. Acad. Sci. 103, 8607-8612.

Van Mooy, B.A.S., Fredricks, H.F., Pedler, B.E., Dyhrman, S.T., Karl, D.M., Koblžek, M, Lomas, M.W., Mincer, T.J., Moore, L.R., Moutin, T., Rappé, M.S, Webb, E.A., 2009. Phytoplankton in the ocean use non-phosphorus lipids in response to phosphorus scarcity. Nature 458, 69-72.

Williams, P.J. LeB, Jenkinson, N.W., 1982. A transportable microprocessor-controlled precise Winkler titration suitable for field station and shipboard use. Limnol. Oceanogr. 27, 576-584.

Williams, P.M., Druffel, E.R.M., 1987. Radiocarbon in dissolved organic carbon in the central North Pacific Ocean. Nature 330, 246-248.

Williams, R.G., 2001. Ocean subduction. In: Steele, J.H., Turekian, K.K., Thorpe, S.A. (Eds.), Encyclopedia of Ocean Sciences. Academic Press, pp. 1982-1993.

Williams, R.G., Roussenov, V., Follows, M.J., 2006. Nutrient Streams and their induction into the mixed layer. Glob. Biogeochem. Cycle 20, GB1016, http: //dx.doi.org/10.1029/2005GB002586.

Xie, S.-P., Saito, K., 2001. Formation and variability of a Northerly ITCZ in a hybrid coupled AGCM: continental forcing and oceanic-atmospheric feedback. J. Clim., $14 ;$, pp. $1262-1276$

Zubkov, M.V., Sleigh, M.A., Burkill, P.H., Leakey, R.J.G., 2000. Picoplankton community structure on the Atlantic Meridional Transect: a comparison between seasons. Prog. Oceanogr. 45, 369-386. 